ASM Sc. J., 13, 2020

https://doi.org/10.32802/asmscj.2020.sm26(2.13)

\title{
Evaluating the Performance of Multi-Project by using Data Envelopment Analysis (DEA)
}

\author{
Ruzanita Mat Rani ${ }^{*}$, Azwa Shawani Kamalul Arifin, Nursyazana Norazman \\ and Wan Nursyahada Nazurah Meor Muhammad Sulaiman \\ Centre of Statistical and Decision Sciences Studies, Faculty of Computer and Mathematical Sciences, \\ Universiti Teknologi MARA, 40450 Shah Alam, Selangor, Malaysia
}

\begin{abstract}
The construction sector, especially in housing development, has rapidly grown in Malaysia. Housing development has been conducted by private and public companies. XYZ Development Sdn Bhd. is one of the private companies in Malaysia involves in housing development. This company has developed 12 housing projects until the year 2016. The previous projects performances are facing problem in terms of total costs and profit. The total costs of the projects are higher, but the profit is lower. Therefore, the performance of multi-projects in XYZ Development Sdn. Bhd. is evaluated by using Data Envelopment Analysis (DEA) which is the BCC model approach. The BCC model is used to determine the efficiency score of each project. Then, for efficient projects, Cross Efficiency is applied to rank the projects. The efficient project also can be as a reference set to the inefficient project. Next, to suggest improvement in order to increase the efficiency of inefficient projects. The results have shown that out of 12 projects, six projects are efficient while the others are inefficient.
\end{abstract}

Keywords: BCC-DEA model, Cross Efficiency, Improvement Percentage

\section{INTRODUCTION}

The construction sector is vitally important because of it have their own mega size and produce huge output, which underpins various economic activities and contributes to the delivery of social and environmental objectives of a nation (Zou \& Sunindijo, 2013). Malaysia as a developing country and one of Asia's tigers is progressing rapidly and is aiming to become a developed nation by 2020 (Bakhtyar et. al., 2013).

A study of Economic Census of Construction conducted by Department of Statistics had stated that in 2015, the total number of the establishment who involved in this census is 40,558 with the compound annual growth rate of 12.9 percent as compared to 22,140 establishments in 2010 (Economic Census 2016- Construction). However, Bank Negara Malaysia stated that construction sector increases moderately in the year $20167.4 \%$ from $20158.2 \%$ (Perkembangan Ekonomi pada Tahun 2016).

There are four sectors in commercial and private sector constructions which are industrial, institutional and commercial, civil engineering and roadwork, and residential. Typically, there are different types of construction firm such as small renovation contractors, general contractors, ownerbuilder, real estate developer, professional construction manager, program manager, package (turnkey) builders and sponsor-builder. Sectors of construction include the facilities and equipment physically attached to buildings. For industrial sector it is used mainly for an economic activity that involved exploitation of mineral resources, transformation of raw materials, and production of goods while for institutional and commercial sector, it used mainly for institutional and commercial purposes, as well as all structures that cannot be included in the residential, industrial, and civil engineering and roads sectors.

XYZ Development Sdn. Bhd. one of the companies involving in the construction sector in Malaysia which mainly focusing on housing development. Nowadays the number of competitors is increasing, so this company has difficulty in getting housing projects. It is because they have

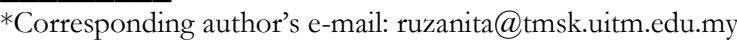


to compete with the new company and established company. Based on the information given by the company, the total costs spent for each project is greater than the profit. Therefore, XYZ Development Sdn. Bhd. wants to maximize the profit and maintain the total costs. Thus, a few actions will be taken to solve the problems.

\section{MATERIALS AND METHODS}

The method that is carried out in this study is discussed in this section. The inputs and output selection is mentioned and BCC-DEA model is described. Cross Efficiency is applied to rank the efficient projects and suggest improvement for inefficient projects.

The selection of input and output variables for project evaluation using BCC-DEA model are selected based on several literature reviews and the availability of data. By considering the information and analysis from several literature reviews and data availability, three inputs and one output variables are identified and are used to evaluate the efficiency of each project.

This study takes three inputs and one output variables into account as the criteria in order to conduct the efficiency analysis. The total number of workers, number of units and total costs are the inputs variables. While, the output variable selected is profit. The summary of inputs and output variables selection is shown in Table 1.

Copper et. al., (2004) stated that DEA is a relatively data-oriented approach for evaluating the performance of a set of peer. It is called Decision Making Units (DMUs) which convert multiple inputs into multiple outputs.

Table 1. Summary of Input and Output Variables Selection

\begin{tabular}{cc}
\hline Input & Output \\
\hline Number of Workers & Profit \\
Number of Units & \\
Total Costs &
\end{tabular}

In this study, DMU refer to project. The efficiency score of each project is evaluated using BCC-DEA model by Banker et al. (1984). The output-oriented BCC-DEA is as follows, Equation (1):

$$
\begin{aligned}
& \theta_{0}=\min \sum_{i=1}^{m} v_{i} x_{i k_{0}}-u_{0} \\
& \text { subject to } \\
& \sum_{i=1}^{m} v_{i} x_{i k}-\sum_{j=1}^{n} u_{j} y_{j k}-u_{0} \geq 0, \sum_{j=1}^{n} u_{j} y_{j k_{0}}=1, \\
& i=1,2, \ldots, m, \quad j=1,2, \ldots, n, \quad v_{i}, u_{j} \geq \varepsilon
\end{aligned}
$$

In Equation (1), where $\theta_{0}$ is the relative efficiency of $D M U_{0} . D M U_{0}$ is DMU under evaluation, $k$ is the DMU index, $j$ is the output index, $i$ is the input index $y_{j k}$ is the value of the $j^{\text {th }}$ output for the $k^{t h}$ DMU, $x_{i k}$ is the value of the $i^{t h}$ input for the $k^{\text {th }}$ DMU, $u_{j}$ is the weight given to the $j^{\text {th }}$ output , $v_{i}$ is the weight given to the $i^{\text {th }}$ input, and $D M U_{0}$ is efficient if $\theta_{0}=1, D M U_{0}$ is inefficient when $\frac{1}{\theta_{0}}<1$. DMUs.

In this multi-project performance evaluation, Cross Efficiency is used to determine the rank of efficient project or to choose the best performance among all 12 projects. Cross Efficiency is calculated using inputs and output weights of efficient DMUs or it based on self-assessment and peer assessment. The Cross-Efficiency matrix by (MarkovitsSomogyi, 2011) is as follows, Equation. (2):

$$
\begin{gathered}
E_{j 0}=\frac{\sum_{i=1}^{m} v_{i 0} x_{i j}-v_{0}}{\sum_{r=1}^{s} u_{r 0} y_{r j}} \\
i=1, \ldots, m ; \quad r=1, \ldots, s . \\
\bar{E}_{0}=\frac{\sum_{j=1}^{n} E_{j 0}}{n} \\
j=1, \ldots, n .
\end{gathered}
$$

where, $E_{j 0}$ is the score for $D M U_{j}$ using optimal weights selected by $D M U_{0}, \bar{E}_{0}$ is the average efficiency score given to $D M U_{0}$. Efficient DMU with the lowest average efficiency score is considered in the first rank.

In order to improve inefficient DMUs, this formula, Equation (3) is used (Ozcan, 2014).

Improvement Percentage $=\frac{1}{\text { Efficiency Score }}-$

These DMUs can improve their efficiency score by increasing their outputs based on the value of improvement percentage. 


\section{RESULTS AND DISCUSSIONS}

In this section, the efficiency score of 12 multi-project in XYZ Development Sdn. Bhd. are evaluated using BCC-DEA model in Equation (1). The model is output-oriented. LINGO software is used to solve the model. The efficiency score obtained must be between $\mathrm{o}$ and 1 . The project's is said to be efficient if the efficiency score $\theta_{0}=1$, while if $\frac{1}{\theta_{0}}<1$ it is inefficient. The efficiency score of all projects of XYZ Development Sdn. Bhd. represented in Table 2.

Table 2. Efficiency score of Multi-Project

\begin{tabular}{cc}
\hline Project & Efficiency Score \\
\hline 1 & 0.8838 \\
2 & 1.000 \\
3 & 0.7263 \\
4 & 0.9150 \\
5 & 0.8949 \\
6 & 0.8507 \\
7 & 1.000 \\
8 & 0.8835 \\
9 & 1.000 \\
10 & 1.000 \\
11 & 1.000 \\
12 & 1.000 \\
\hline
\end{tabular}

As the results show that out of 12 multi-projects, only six projects obtained efficiency score equal to one. The efficient projects are project 2, project 7, project 9, project 10, project 11 and project 12. However, for project 1, project 3 , project 4 , project 5 , project 6 and project 8 are inefficient as their efficiency score are less than one.

The results obtained from BCC-DEA model for the multi-project shows that there is more than one projects are efficient. Since six out of 12 projects are efficient, Cross Efficiency is applied in order to determine the best project performance using Equation (2). The efficient project with the lowest average efficiency score is considered in the first rank.
Table 3. Ranking of Efficient Multi-Project

\begin{tabular}{ccc}
\hline DMU & $\begin{array}{c}\text { Average } \\
\text { Efficiency } \\
\text { Score }\end{array}$ & Rank \\
\hline 2 & 2.3311 & 3 \\
7 & 4.2907 & 5 \\
9 & 1.4243 & 1 \\
10 & 4.9110 & 6 \\
11 & 2.0231 & 2 \\
12 & 3.2360 & 4 \\
\end{tabular}

Based on Table 3, project 9 has the lowest value for average efficiency score. Project 9 is in the first rank followed by project 11, project 2, project 12 and project 7 while project 10 in the last rank.

Table 4 shows project 9 used 29 workers who work on two units with the total costs is RM392,610.50 and profit is RM107,389.50. Project 9 display the best combination of inputs used and output produced.

Table 4. Original Data Sets of Efficiency Projects

\begin{tabular}{|c|c|c|c|c|}
\hline \multirow[b]{3}{*}{ 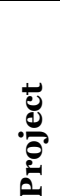 } & & Input & & \multirow[t]{2}{*}{ Output } \\
\hline & & umbe & & \\
\hline & $\begin{array}{c}\text { Number of } \\
\text { Workers }\end{array}$ & $\begin{array}{c}\text { of } \\
\text { Unit }\end{array}$ & $\begin{array}{c}\text { Total Costs } \\
\text { (RM) }\end{array}$ & $\begin{array}{l}\text { Profit } \\
\text { (RM) }\end{array}$ \\
\hline
\end{tabular}

\begin{tabular}{cccrr}
\hline $\mathbf{2}$ & 34 & 6 & 338610.50 & 81389.50 \\
7 & 25 & 10 & 1657633.50 & 442366.50 \\
$\mathbf{9}$ & 29 & 2 & 392610.50 & 107389.50 \\
$\mathbf{1 0}$ & 27 & 4 & 1332049.92 & 347950.08 \\
$\mathbf{1 1}$ & 27 & 16 & 3945330.66 & 1334669.34 \\
$\mathbf{1 2}$ & 22 & 22 & 3595980.92 & 804019.08 \\
& & & & \\
\hline
\end{tabular}

For inefficient projects, the improvement percentages are calculated using Equation (3). The improvement percentage tells how much the output need to be increased. 
Table 5. Improvement Percentage of Inefficient Projects

\begin{tabular}{cccc}
\hline DMU & $\begin{array}{c}\text { Efficiency } \\
\text { Score }\end{array}$ & $\begin{array}{c}\text { 1/ } \\
\text { Efficiency } \\
\text { Score }\end{array}$ & $\begin{array}{c}\text { Improvement } \\
\text { Percentage (\%) }\end{array}$ \\
\hline 1 & 0.8838 & 1.1315 & 13.15 \\
3 & 0.7263 & 1.3769 & 37.69 \\
4 & 0.9150 & 1.0930 & 9.29 \\
5 & 0.8949 & 1.1175 & 11.75 \\
6 & 0.8507 & 1.1756 & 17.55 \\
8 & 0.8835 & 1.1319 & 13.19 \\
\hline
\end{tabular}

Based on Table 5, the improvement percentage shows the percent of output (profit) need to be improved by each of inefficient project to become efficient. Project 3 shows the highest improvement percentage among six inefficient projects. Project 3 can improve its efficiency by increasing output up to $37.69 \%$. Likewise, project 1, project 4, project 5 , project 6 and project 8 can do so with approximately $13.15 \%, 9.29 \%$, $11.75 \%, 17.55 \%$ and $13.19 \%$ increases, respectively.

\section{CONCLUSION}

This study is analysing the performance of construction company conducting multi-project in housing development. The efficiency score of each project had been determined. The efficient projects are ranked using Cross Efficiency. Project 9 in the first rank. The improvement percentage of each output of each inefficient project is determined.

\section{ACKNOWLEDGEMENT}

This study was made possible by the continuous support from Universiti Teknologi MARA Grant No. 600IRMI/DANA 5/3/LESTARI (0130/2016). 


\section{REFERENCES}

Bakhtyar, B., Zaharim, A., Sopian, K. \& Moghimi, S. 2013, Housing for poor people: A review on low cost housing process in Malaysia. WSEAS Transactions on Environment and Development, 9(2), pp. 126-136.

Banker, R. D., Charnes, A. \& Cooper, W. W. 1984, Some models for Estimating Technical and Scale Inefficiencies in Data Envelopment Analysis. Management Science, 30(9), pp. 1078-1092.

Cooper, W.W., Seiford, L.M. \& Zhu, J. (Eds) 2004, Handbook on Data Envelopment Analysis (2 ${ }^{\text {nd }}$ edition), Boston, Kluwer.
Economic Census 2016- Construction 2017,

Markovits-Somogyi, R. 2011, Ranking efficient and inefficient decision making units in data envelopment analysis. International Journal for Traffic and Transport Engineering, 1 (4), pp. 245-256.

Ozcan, Y.A. 2014, Health Care Benchmarking and Performance Evaluation, International Series in Operations Research \& Management Science 210, Springer Science+Business Media New York 2014 .

Perkembangan Ekonomi pada Tahun 2016.

Zou, P. X. W. \& Sunindijo, R. Y. 2013, Skills for managing safety risk, implementing safety task, and developing positive safety climate in construction project. Automation in Construction, 34 (9), pp. 92-100. 